\title{
REAJUSTES ABUSIVOS DOS PLANOS DE SAÚDE COLETIVOS COM BASE NOS CUSTOS OPERACIONAIS: VIOLAÇÃO DAS NORMAS CONSTITUCIONAIS E CONSUMERISTAS
}

\author{
ABUSIVE READJUSTMENTS OF COLLECTIVE PRIVATE HEALTH INSURANCE \\ CONTRACTS BASED ON OPERATING COSTS: VIOLATION OF \\ CONSTITUTIONAL AND CONSUMERISTAS RULES IN FORCE
}

\author{
${ }^{1}$ Joseane Suzart Lopes da Silva
}

\section{RESUMO}

Trata-se de artigo que versa sobre os constantes reajustes abusivos dos contratos coletivos de assistência suplementar à saúde com base nos custos operacionais, gerando uma flagrante violação às normas constitucionais e consumeristas vigentes. $\mathrm{O}$ problema consiste nos malefícios causados por tais majorações para inúmeros usuários, tendo sido identificado através do alto número de queixas nos órgãos públicos competentes e de demandas judiciais individuais e coletivas. Justifica-se a seleção do tema com esteio em dois argumentos basilares, sendo o primeiro concernente ao elevado número de planos de saúde coletivos na atualidade, eis que as operadoras não mais almejam comercializar os contratos individuais familiares; e o segundo referente ao fato de que a Agência Nacional de Saúde Suplementar (ANS) limita-se a fixar o percentual de reajuste atinente aos custos operacionais apenas para os contratos individuais. Objetiva-se, inicialmente, conceituar e caracterizar os contratos coletivos de planos de saúde, diferenciando-os dos individuais e/ou familiares, bem como apresentar as espécies existentes o que concretizar-se-á no primeiro tópico. Em seguida, pretende-se explicitar em que consistem os reajustes com lastro nos custos operacionais, distinguindoos das demais formas de majoração. Transpor-se-á, após, a explanação para o tratamento do desrespeito às normas constitucionais e consumeristas, à função social do contrato e à boa-fé objetiva dos consumidores. Foram utilizados os métodos hipotético dedutivo, hermenêutico e argumentativo, a vertente crítico-metodológica, e a pesquisa exploratória de natureza bibliográfica. Conclui-se no sentido de que a prevenção e o combate dos malfadados reajustes devem constituir atribuição expressa da ANS mediante a edição de resolução específica acerca da temática, visto que a função social do contrato e a boa-fé objetiva dos usuários não poderão continuar sendo transgredidas, engendrando, frequentemente, a rescisão do contrato pela impossibilidade da continuação do pagamento.

Palavras-chave: Planos de saúde coletivos, Reajustes operacionais, Constituição federal, Cdc

\footnotetext{
${ }^{1}$ Doutora em Direito pela Universidade Federal da Bahia - UFBA, Bahia (Brasil). Professora pela Universidade Federal da Bahia - UFBA, Bahia (Brasil)
} 


\begin{abstract}
This article deals with the constant abusive readjustments of collective private health insurance contracts based on operating costs, resulting in a violation of constitutional and consumeristas rules in force. The problem is the harm caused by such increases for many users, have been identified by the high number of complaints in public agencies and individual and collective lawsuits. The topic selection is justified by mainstay in two basic arguments, the first concerning the high number of collective health plans today, behold, operators no longer aim to market the individual / family contracts; and the second referring to the fact that the National Health Agency (ANS) is limited to fixing the adjustment percentage regard to the operational costs only for the individual contracts. The objective is to initially conceptualize and characterize the collective health insurance contracts, differentiating them from the individual and / or family, as well as presenting the species which will be implemented within the first subject. Then intended to clarify what constitute the adjustments backed in operating costs, distinguishing them from other forms of increase. It will be transposed, after the explanation for the treatment of disrespect to the constitutional rules and consumer rights, the social function of the contract and the objective good faith of consumers. The hypothetical deductive methods, hermeneutic and argumentative were used, the critical methodological aspect, and exploratory research literature nature. It was concluded towards the prevention and combating of the star-crossed adjustments must be express conferral of ANS by specific resolution editing on the theme, as the social function of the contract and the objective good faith users may not remain transgressed, engendering often the termination of the contract by the impossibility of continued payment.
\end{abstract}

Keywords: Keywords: collective health plans, Operating adjustments, Constitutional standards, Cdc 


\section{INTRODUÇÃO}

A precariedade do sistema público de saúde brasileiro propiciou o surgimento e o célere desenvolvimento do mercado suplementar, conduzindo milhares de indivíduos a optar pela contratação de planos particulares, efetivando o pagamento mensal em busca de segurança e qualidade no atendimento. A quantidade de usuários da assistência suplementar no País veio crescendo intensamente na última década, principalmente, mediante a inserção de integrantes da classe média no setor e também de outros advindos das camadas sociais menos abastadas, que se esforçam para terem um plano privado, gerando um panorama interessante pelo elevado número de contratantes.

Os contratos de assistência suplementar à saúde, desde a fase inicial da sua origem, permitiam a contratação por sujeitos e também para o seu grupo familiar, caracterizando-se como planos individuais ou familiar, bem como poderiam ser subscritos por pessoas jurídicas em prol de indivíduos a essa vinculados. Tratam-se, nessa última hipótese, dos planos de saúde coletivos firmados por empresas em benefício dos seus trabalhadores, por fundações ou associações em prol dos seus filiados ou por demais pessoas jurídicas que objetivassem a proteção da saúde de um grupo específico de pessoas.

No entanto, nos últimos anos, tem-se evidenciado que a maioria das operadoras de planos de saúde não mais têm ofertado planos de saúde individuais e familiares, limitando-se a lidar apenas com os contratos coletivos. Tal tendência tem sido incentivada por dois fatores essenciais, consistindo o primeiro deles na ausência de interferência da Agência Nacional de Saúde Suplementar (ANS) na fixação do percentual anual de reajuste das mensalidades dos planos coletivos. O segundo aspecto concerne à possibilidade de rescisão injustificada da relação contratual por parte da empresa gestora do plano de saúde, eis que a Lei n. 9.656/98 somente a veda para as espécies individuais.

Justifica-se, nessa senda, a seleção do tema diante da sua atualidade e relevância, visto que, hodiernamente, a maioria dos planos de saúde são coletivos, já que os individuais não estão mais sendo disponibilizados pela maioria das empresas do ramo. Ademais, a dita agência reguladora não estabelece os índices dos reajustes operacionais a serem aplicados anualmente, alegando que a pessoa jurídica contratante e a operadora poderão discuti-los em condições igualitárias e alcançá-los sem a sua necessária participação. A quantidade de reclamações de usuários de planos coletivos tem-se elevado intensamente perante os órgãos públicos incumbidos da sua proteção e as ações estão pululando ascendentemente na esfera judiciária.

O problema a ser tratado corresponde à indagação acerca de como se pode prevenir e combater os reajustes arbitrários encetados com base nos custos operacionais para os contratos 
coletivos de assistência suplementar à saúde, visto que a autarquia responsável pelo setor se exime de atuar. Arregimenta-se como hipótese central a existência de uma vinculação direta e expressa da ocorrência dos reajustes abusivos das mensalidades dos planos de saúde coletivos com finco naquelas despesas com a inércia da ANS de acompanhamento mais profícuo do setor e da regulamentação mais apropriada e satisfatória.

Objetiva-se, em face do exposto, inicialmente, discorrer sobre o conceito dos contratos de assistência suplementar à saúde e as suas principais características, destacando-se os regimes jurídicos previstos pela Lei n. 9.656/98 e os tipos de liames jurídicos admitidos. Em seguida, pretende-se explicitar em que consistem os reajustes com fundamento nos custos operacionais, diferenciando-os dos demais admitidos pela legislação vigente. Na condição de terceiro objetivo, apresenta-se a necessária análise da violação das normas constitucionais que erigiram a proteção da saúde e do consumidor à condição de direitos fundamentais. O quarto objetivo equivale à imprescindível verificação das normas consumeristas transgredidas pelas indigitadas majorações, observando-se também a afetação da boa-fé objetiva dos usuários e da função social dos contratos. O quinto e derradeiro objetivo destina-se à busca de uma solução satisfatória para o problema enfrentado visando à efetiva proteção dos interesses e direitos dos consumidores, sem desconsiderar também que as operadoras necessitam de valores justos para a sua manutenção.

Os temas centrais a serem trabalhados encontram-se inseridos nos objetivos acima propostos, não se fazendo necessária sua repetição, para que não se estenda demasiadamente a parte introdutória. Para a confecção desse artigo, foram utilizados os métodos clássicos hipotético dedutivo, dialético e hermenêutico. No que concerne aos métodos jurídicos, os modelos teóricos selecionados foram o hermenêutico e o argumentativo; quanto às linhas metodológicas, seguiu-se a crítico-metodológica; dentre os tipos genéricos de investigação, utilizou-se a jurídico-exploratória, a jurídico-projetiva e prospectiva. Fora ainda manejada a pesquisa exploratória de natureza bibliográfica, examinando-se obras, artigos e decisões judiciais proferidas sobre o assunto. No campo das técnicas, o artigo sedimenta-se na documentação indireta, abrangendo a pesquisa bibliográfica. Ressalta-se também que foram extraídos dados informativos dos sites da Superintendência Estadual de Proteção e Defesa do Consumidor (PROCON-BA), Ministério Público do Estado da Bahia (MPBA) e Juizados Especializados na materia que integram o Poder Judiciário local. 


\section{PLANOS DE SAÚDE COLETIVOS: CONCEITO E ESPÉCIES}

Os planos privados de assistência à saúde, conforme dispõe o art. 1-º, inciso I, da Lei n. 9.656/98, constituem prestações continuadas de serviços ou cobertura de custos assistenciais a preço estabelecido de forma prévia ou posterior, por prazo indeterminado, com a finalidade de garantir, sem limite financeiro, a assistência à saúde dos contratantes, englobando atendimento médico, hospitalar e odontológico.

Para a concretização do objeto contratual, as operadoras de planos de saúde podem apresentar aos consumidores uma lista de profissionais e/ou serviços de saúde, configurando-se uma rede credenciada, contratada ou referenciada. Será possível também as empresas do setor facultarem aos contratantes a livre escolha de profissionais e estabelecimentos de saúde que não integrem a dita lista, devendo os mesmos efetivarem os pagamentos devidos, para solicitarem posterior reembolso (BOTTESINI; MACHADO, 2010, p. 78).

A compreensão do conceito e das espécies de planos de saúde coletivos é de fundamental importância para o enfrentamento do problema tratado, assim como das principais características de tais contratos. Assim sendo, destina-se o presente tópico a discorrer, inicialmente, sobre em que consistem os planos de saúde coletivos, apresentando as distinções diante dos contratos individuais ou familiares, para, a posteriori, adentrar nos reajustes abusivos.

\subsection{REGIMES OU TIPOS DE CONTRATAÇÕES}

Os regimes ou tipos de contratações encontram-se previstos na Resolução Normativa n. 195, de 14 de julho de 2009¹, editada pela Agência Nacional de Saúde Suplementar (ANS) e são classificados em individual ou familiar e coletiva por adesão. $\mathrm{Na}$ contratação individual ou familiar, as pessoas físicas em geral poderão aderir, livremente, ao plano de saúde escolhido, quer estejam sozinhas ou acompanhadas por seu grupo familiar. A contratação coletiva por adesão é definida como aquela que oferece cobertura da a tenção prestada à população que mantenha vínculo de caráter profissional, classista ou setorial com determinadas pessoas jurídicas. Importante registrar que o grupo familiar do beneficiário titular, até o terceiro grau de parentesco consanguíneo, até o segundo grau de parentesco por afinidade, bem como o cônjuge ou

\footnotetext{
${ }^{1}$ Foram inicialmente disciplinados na Resolução CONSU no -14 , de 3 de novembro de 1998.
} 
companheiro do mesmo, podem aderir ao plano de saúde coletivo, desde que previsto contratualmente (SCHAEFER, 2004, p. 67).

A rescisão do vínculo do titular do plano familiar com a operadora não extingue o contrato, sendo assegurado aos dependentes, desde que já inscritos, o direito à manutenção nas mesmas condições contratuais, competindo-lhes a assunção das obrigações decorrentes, conforme disposto pelo art. $3^{\circ}$, parágrafo $1^{\circ}$, da aludida Resolução. No entanto, caso se verifique a ocorrência de fraude ou o não pagamento da mensalidade por parte do titular, o vínculo jurídico não será mantido com relação aos dependentes, conforme disposto pelo parágrafo $2^{\circ}$ do aludido dispositivo.

Os planos de saúde coletivos podem ser firmados entre operadoras e conselhos profissionais e entidades de classe, nos quais seja necessário o registro para o exercício da profissão. Sindicatos, centrais sindicais e respectivas federações e confederações, bem como associações profissionais legalmente constituídas, cooperativas que congreguem membros de categorias ou classes de profissões regulamentadas e caixas de assistência e fundações de direito privado que se enquadrem nas disposições daquela Resolução também optar pela contratação coletiva. O mesmo se verifica com as entidades previstas na Lei n. 7.395, de 31 de outubro de 1985, e na Lei n. 7.398, de 4 de novembro de 1985; e outras pessoas jurídicas de caráter profissional, classista ou setorial não previstas nos incisos anteriores, desde que autorizadas pela Diretoria de Normas e Habilitação de Operadoras (DIOPE) da ANS (FERNANDES NETO, 2002, p. 89).

Diante do fenômeno denominado de "falsa coletivização", ou seja, a criação de pessoas jurídicas com a finalidade específica de contratarem planos de saúde coletivos, o art. 10 da RN multicitada estabelece que somente poderão formalizar tal vínculo após decorrido o prazo de 01 (um) de constituição. Com relação aos conselhos profissionais, entidades de classe e sindicatos, dispensa-se o cumprimento deste lapsus temporis.

No plano privado de assistência à saúde por adesão, não poderá ser exigido o cumprimento de prazos de carência, desde que o beneficiário ingresse no plano em até 30 (trinta) dias da celebração do contrato coletivo, conforme previsto no art. 11 da RN n. 195/09. Nos casos de doenças ou lesões preexistentes, o contrato poderá conter cláusula de agravo ou de cobertura parcial temporária, em conformidade com os ditames da resolução específica em vigor (CARVALHO SOBRINHO, 2001, p. 66).

O pagamento pelos serviços prestados pela operadora do plano de saúde será da responsabilidade da pessoa jurídica contratante, não podendo ser efetuada cobrança das 
contraprestações pecuniárias diretamente dos beneficiários. Estabelece o art. 15 da Resolução em epígrafe que o contrato deverá conter cláusula específica que discipline os casos de inadimplemento por parte dos beneficiários, bem como as condições e prazo de pagamento.

A contratação coletiva empresarial é aquela em que há o oferecimento de cobertura da atenção prestada à população delimitada e vinculada à pessoa jurídica por relação empregatícia ou estatutária. Podem ser abrangidos, desde que há previsão contratual, os sócios, os administradores, os demitidos ou aposentados, que tenham sido vinculados anteriormente à pessoa jurídica contratante, ressalvada a aplicação do disposto no caput dos artigos 30 e 31 da Lei n. 9.656/98. Ademais, também podem ser incluídos: os agentes políticos; os trabalhadores temporários; os estagiários e menores aprendizes; e o grupo familiar até o terceiro grau de parentesco consanguíneo, até o segundo grau de parentesco por afinidade, cônjuge ou companheiro dos empregados e servidores públicos, bem como dos demais beneficiários. Nos planos de saúde coletivos empresariais que tenham 30 (trinta) ou mais participantes, será inadmissível cláusula de agravo ou cobertura parcial temporária quanto às lesões ou doenças preexistentes, bem como a previsão de prazos de carência (RIZZATTO NUNES, 2000, p. 23).

Determina o art. 17 da Resolução sub examine que, no contrato coletivo de assistência à saúde suplementar, devem ser registradas as condições que ensejam a rescisão contratual ou da suspensão de cobertura. A ANS, por meio deste dispositivo, tentou regulamentar as hipóteses de extinção do vínculo contratual entre a operadora e a pessoa jurídica contratante, mas deix ou grande margem de arbítrio para a primeira, dando margem à inserção de cláusulas abusivas. O ideal seria que a Lei n. 9.656/98 fosse alterada para contemplar a impossibilidade de rescisão unilateral do contrato, da mesma forma como preconizado para os planos individuais e familiares (CARVALHO SOBRINHO, 2001, p. 55).

O parágrafo único do mencionado art. 17 prevê que os contratos de planos privados de assistência à saúde coletivos, por adesão ou empresarial, somente poderão ser rescindidos imotivadamente após a vigência do período de doze meses e mediante prévia notificação da outra parte, com antecedência mínima de sessenta dias. Este dispositivo termina por chancelar a possibilidade de extinção unilateral do liame contratual, gerando sérios prejuízos para os consumidores, eis que objetivam manter a contratação por prazo superior a 01 (um) ano. Ademais, neste período temporal, os usuários não tiveram nem mesmo condições de bem usufruir dos produtos e serviços contratados (BOTTESINI; MACHADO, 2010, p. 89). 
Observa-se que a multicitada Resolução apresentou algumas inovações no que concerne aos planos coletivos, mas estas não foram suficientes para a efetiva garantia dos interesses e direitos dos usuários. Torna-se imperiosa a devida alteração na Lei n. 9.656/98 de modo que os contratos coletivos de assistência suplementar à saúde restem melhor regulamentados, impedindo-se a rescisão unilateral e prevendo o controle direto e expresso dos reajustes das contraprestações pecuniárias por parte da Autarquia competente.

No mercado de saúde suplementar, observa-se uma tendência das empresas $\mathrm{a}$ oferecerem apenas os planos ou seguros coletivos, e não mais os de natureza individual. A contratação coletiva poderá ocorrer por pessoas jurídicas interessadas em prol de um conjunto de indivíduos que estejam de qualquer forma a elas vinculados mediante liame trabalhista ou outra modalidade de relação cível. O estabelecimento dos valores das contraprestações pecuniárias dos planos e seguros de saúde coletivos dependerá da livre negociação realizada entre a pessoa jurídica contratante e a empresa fornecedora. A Agência Nacional de Saúde Suplementar (ANS) não intervirá nas discussões sobre a fixação dos preços dos produtos contratados em caráter coletivo. Esta característica constitui um dos fatores principais que conduzem as empresas que atuam no campo da saúde suplementar a preferirem a gestão de planos e seguros apenas coletivos (CARVALHO SOBRINHO, 2001, p. 45).

Outro aspecto que contribui para que as operadoras e seguradoras privilegiem a oferta de contratos coletivos constitui a presença de um conjunto estável de contratantes. O plano ou seguro coletivo, quando firmado com a pessoa jurídica interessada, congrega todos os que estejam a esta vinculados. Esta é a nota essencial dos planos ou seguros coletivos, sendo um aspecto positivo que interessa bastante as empresas do setor. $\mathrm{Na}$ contratação coletiva por adesão, os que estejam vinculados à pessoa jurídica contratante podem ou não aderir ao plano ou seguro, mas, em geral, concordam com a proposta. A presença de uma massa constante de usuários e a segurança quanto à recepção das contraprestações pecuniárias mensalmente estimulam as operadoras e seguradoras a optarem pela operacionalização tão-somente de contratos coletivos. Estas empresas apegam-se, principalmente, ao fato de que, ao cabo de cada período mensal, a própria pessoa jurídica contratante fará o depósito das mensalidades, gerando uma segurança na relação estabelecida (MARANHÃO, 2003, p. 43).

A Lei n. 9.656/98, em nenhum dos seus dispositivos, autoriza as operadoras e seguradoras que atuam no ramo da saúde suplementar, a operacionalizarem apenas contratos coletivos. Estando inseridas no mercado de saúde privada, tais empresas não podem apenas disponibilizar ao público consumidor os produtos que lhes sejam mais favoráveis em virtude 
da liberdade de fixação de preços e da ausência da fiscalização da autarquia reguladora. Autorizadas para ofertarem serviços de saúde, as operadoras e seguradoras não estão liberadas para agirem sem freios e sem limites. E estas pessoas jurídicas não podem questionar que fazem parte do ramo de atividade privada e a sua autonomia, assegurada na Constituição Federal, está sendo desrespeitada. Isso porque os serviços privados de saúde são atividades que suplementam a atuação do poder estatal, e as empresas particulares que almejem integrar o setor devem ter a consciência exata de que são obrigadas a agir com base nos princípios que o norteiam, quais sejam: universalidade, igualdade e continuidade (BOTTESINI; MACHADO, 2010, p. 67).

Os planos e seguros de saúde devem ser colocados à disposição de todo indivíduo que tenha interesse em contratá-los, sendo vedada qualquer discriminação. O art. 16, inciso I, da Lei n. 9.656/98, estabelece que a indicação das condições de admissão constitui um dos requisitos dos contratos, regulamentos ou condições gerais dos produtos. Entretanto, este dispositivo não deve ser interpretado no sentido de que as operadoras e seguradoras de saúde podem prever como requisito para o ingresso no plano ou seguro saúde que o consumidor esteja vinculado a uma certa pessoa jurídica. Admitir-se esta situação seria discriminar aquelas pessoas que vivam de rendas próprias, as que estejam desempregadas, e as que, mesmo sendo trabalhadoras, seus empregadores não concordam em contratar plano ou seguro de saúde. Haveria, portanto, uma violação aos ditames constitucionais que asseguram a todos os brasileiros o tratamento igualitário, isento de preconceitos e prejulgamentos. Os consumidores, quer integrem certa pessoa jurídica ou não, devem ser respeitados quanto ao propósito de contratarem um plano ou seguro de saúde (BOTTESINI; MACHADO, 2010, p. 68).

A maioria das operadoras de planos e/ou seguros de saúde, com o objetivo de reforçarem o propósito de não disponibilizarem mais contratos individuais, deixaram de apresentar mais qualquer publicidade neste sentido. Entretanto, mesmo que não haja divulgação para o conhecimento do público consumidor, estas empresas são obrigadas a prestarem os serviços de assistência à saúde suplementar para os que necessitam em caráter individual. Nelson Nery Júnior afirma que, sendo a saúde uma necessidade essencial para os indivíduos na condição de consumidores, ainda que certa operadora ou seguradora especializada em saúde não realize publicidade sobre o assunto, terá o dever de contratar, já que incidirá o que se denomina "relação paracontratual" (2014, p. 345), caracterizando-se "a contratação forçada (do alemão diktierter Vertrag; do francês, contrat imposé)" (SAVATIER, 1952, p. 23). 


\subsection{CARACTERÍSTICAS DOS CONTRATOS DE ASSISTÊNCIA SUPLEMENTAR À SAÚDE}

Os contratos celebrados entre as operadoras de planos e seguros de saúde e os consumidores apresentam características específicas que os diferenciam dentro do universo contratual existente neste País. Dada a singularidade das relações contratuais estabelecidas entre as pessoas jurídicas que atuam no ramo da saúde suplementar e as pessoas que necessitam dos seus serviços, uma breve análise dos aspectos específicos que caracterizam estes contratos pode contribuir para a melhor elucidação do objeto fundamental deste estudo.

A bilateralidade e a reciprocidade estão sempre presentes nos contratos de planos de saúde. De um lado da relação, encontram-se os consumidores que, para o atendimento das suas necessidades em termos de assistência à saúde, estão predispostos a subscreverem uma proposta e efetivarem, mensalmente, o pagamento de uma mensalidade, e de outro, os fornecedores que, atuando de acordo com uma das formas previstas na classificação acima exposta, visam satisfazer a pretensão dos usuários. Há um liame jurídico entre as operadoras e os consumidores, caracterizandose, pois, como sinalagmático e oneroso (GOMES, 1967, 1972, 1977, 1983).

Os contratos de assistência suplementar à saúde constituem-se mediante a simples adesão do consumidor a formulários previamente elaborados pelos fornecedores. No que concerne aos planos coletivos, são estabelecidos através de estruturas padronizadas apresentadas pelas operadoras em face da pessoa jurídica contratante. Tanto nos contratos individuais quanto nos coletivos, observa-se que os consumidores não conseguem propor alterações na estrutura contratual apresentada, tendo que aceitar em bloco o que vem a ser ditado pelo fornecedor. Quanto aos planos de saúde coletivos, a vulnerabilidade do consumidor é ainda mais flagrante, visto que a pessoa jurídica contratante disponibiliza uma estrutura pronta e acabada (GILMORE, 1995, p. 67).

Os planos de saúde são também contratos de natureza aleatória, uma vez que a prestação das operadoras de planos de saúde depende de um risco futuro e incerto (GIORDANO, 1951, p. 45). Aproveitam-se as empresas do ramo desta justificativa para alegarem que não têm condições de fixarem, de forma prévia, os gastos a serem concretizados. Contudo, as operadoras de planos de saúde não podem fazer uso de cláusulas genéricas para disporem sobre os aumentos periódicos com base nos custos 
operacionais, devendo haver referência a índices que reflitam a realidade do setor, a fim de se evitar futuros prejuízos para os consumidores (WEICHERT, 2004, p. 56).

A expressão "contratos cativos de longa duração" tem sido atribuída, por Cláudia Lima Marques, às relações contratuais que terminam perpassando por um extenso período de tempo, uma vez que, principalmente, para os consumidores, não será interessante que o vínculo finalize após prazo de pequeno decurso (2014, p. 235). Os planos de saúde são contratos cativos porque os consumidores, normalmente, quando os subscrevem não necessitam fazer uso imediato dos serviços disponibilizados, e mesmo se precisassem, não poderiam fazê-lo, diante dos prazos de carência estipulados. Os usuários contribuem durante certo tempo para uso posterior, e quanto mais o tempo transcorre, intensifica-se a vinculação destes ao plano ou seguro de saúde, dado que, caso partam para uma outra relação contratual, perderão os valores já pagos e terão que se submeter a novo período de carência. A longevidade que se espera dos contratos de planos de saúde conduziu Ronaldo Porto Macedo Júnior a denominá-los de “contratos relacionais" (1998, p. 291).

Por serem contratos de duração extensa, os planos de saúde podem, para a manutenção do equilíbrio da relação contratual, rever a contribuição pecuniária com que arcam os consumidores, mas desde que respeitados os parâmetros legais. Todavia, constantemente aumentos abusivos são impostos, sob a alegação de que as receitas arrecadadas pelas empresas que atuam no ramo da saúde suplementar não estão sendo suficientes para a manutenção dos serviços previstos em sede contratual.

A vulnerabilidade dos consumidores é flagrante diante dos planos de saúde, uma vez que atrelados a estes de forma duradoura - sem a pretensão de findar a relação formalizada, pois busca-se uma proteção futura e o não-desperdício do quanto já pago - terminam aceitando os abusos cometidos. Por tal razão, Cláudia Lima Marques afirma que constituem “contratos sui generis”, devendo ser analisados e interpretados com cautela, para a devida coibição das majorações praticadas (2014 p. 394).

Nos contratos de larga duração, a presença de cláusulas abusivas e demais posturas iníquas causam maiores impactos negativos para os consumidores, uma vez que a relação contratual protrai-se no tempo e vai sendo maculada com os efeitos nefastos das estipulações indevidas. Diante da singularidade dos contratos duradouros, Ricardo Lorenzetti afirma que nestes não há a previsão material dos bens, mas tão-somente normas procedimentais, já que a evolução tecnológica poderá imprimir modificações na prestação da obrigação (2000, p. 119). Em tais espécies de contratos, o preço definitivo, também, não pode ser estipulado, visto que, 
em razão da indefinição do lapsus temporis que deverá tramitar, incidem transformações inflacionárias, mas urge que critérios seguros sejam obedecidos.

Em razão da especificidade das relações advindas da contratação dos planos e seguros de saúde, que devem ser duráveis e não executáveis em breve espaço de tempo, há que se ter uma enorme cautela com as disposições presentes nos instrumentos a que os consumidores, simplesmente, aderem. O conteúdo das cláusulas inerentes aos contratos relativos à assistência à saúde suplementar deve ser, rigorosamente, avaliado, para que não seja supedâneo de aumentos abusivos - posteriormente praticados - ou de outras práticas que limitem os direitos dos usuários (GHERSI; WEINGARTEN; IPPOLITO, 1999, p. 134).

Nos “contratos relacionais", a durabilidade razoável da relação jurídica é um dos fatores fundamentais que os diferenciam dos demais. Pressupondo uma existência por período de tempo ilimitado, os consumidores devem estar atentos às cláusulas que os integrarão, porquanto estas não podem ser petrificadas, em outras palavras, cujo conteúdo se pretenda considerar atualizado pela vida inteira da relação contratual. Assim, como bem afirma o citado doutrinador, nestes contratos, as “cláusulas substantivas" deverão ser substituídas pelas “processuais”. Isso significa afirmar que as partes devem estar reunidas, de modo contínuo, para discutirem as condições de execução do contrato (MACEDO JÚNIOR, 1998, p. 147-166).

Ora, os planos e seguros de saúde, indubitavelmente, são contratos relacionais, mas as empresas responsáveis por seu monitoramento não estão preocupadas em manterem um diálogo perene com os consumidores, a fim de debaterem sobre os termos contratuais. O que se verifica é a presença de cláusulas, muitas vezes já abusivas desde a sua origem, e o completo desinteresse das empresas do ramo em criarem canais de discussão para a tentativa de adequar- se a relação jurídica à conjuntura atual. Na realidade, quanto menos diálogo, melhor e quanto mais se mantém um contrato desatualizado, de mais chances dispõem as referidas operadoras para imporem suas práticas abusivas.

Nos contratos de longa duração, em geral, deve haver uma preocupação constante com o teor das cláusulas contratuais, e com maior razão, quando tratam de relações jurídicas cujo objeto constitui a saúde das pessoas. Lorenzetti argumenta que o contrato de "medicina prepaga", mesmo celebrado no âmbito privado, tem por objetivo a proteção da saúde concebida como um direito fundamental. Desta forma, além de serem qualificados como contratos de duração extensa, os planos e seguros de saúde lidam com o direito essencial dos indivíduos - cujo tratamento indevido pode gerar a eliminação da vida - exigindo, portanto uma rigorosa fiscalização do conteúdo das normas que os guarnecem. Uma relação contratual desse tipo não pode ser tratada 
como um vínculo comum, devendo-se admitir que "A prestação de um direito fundamental pode desequilibrar a lógica contratualista, já que se concedem direitos e ações que seriam impensáveis em um contrato comum" (1998, p. 369).

Os planos e seguros-saúde também se caracterizam pela necessária constituição de um fundo mútuo, ou seja, pela formação de uma massa financeira que servirá de lastro para que as empresas gestoras atendam às demandas dos usuários. Todos os consumidores devem, mensalmente, efetivar o pagamento de contraprestações, mas a utilização dos serviços disponibilizados dependerá da necessidade de cada usuário, permitindo que as operadoras e seguradoras angariem recursos financeiros suficientes para comporem fundos que servirão para a garantia do atendimento de todos os contratantes. Antônio Joaquim Fernandes Neto destaca que os planos e seguros de saúde são constituídos por meio de captação de poupança popular e destinam-se a "prover o custeio das despesas individuais dos contribuintes e seus dependentes", afirmando também que "a saúde privada, cuja principal fonte de custeio são os fundos mantidos pelas operadoras de planos privados de assistência à saúde, orienta-se pela solidariedade e pelo mutualismo, fortes características herdadas dos contratos de seguro e dos fundos de previdência” (2002, p. 98).

\section{REAJUSTES COM BASE NOS CUSTOS OPERACIONAIS}

Os contratos de assistência suplementar à saúde sofrem reajustes distintos e que suscitam o conhecimento prévio do leitor para se possa compreender melhor em que consistem os aumentos com base nos custos operacionais. Dessa forma, antes de discorrer sobre o problema específico objeto deste artigo, far-se-á uma breve análise das espécies de majorações incidentes nos planos de saúde, a fim de que não sejam confundidas com as despesas para a operacionalização das atividades inerentes.

\subsection{ESPÉCIES DE REAJUSTES APLICÁVEIS AOS PLANOS DE SAÚDE}

Todo e qualquer negócio jurídico oneroso pressupõe a realização de uma prestação por uma das partes e a contraprestação no que concerne à outra. É natural que, no universo contratual, ao se comprometer uma das partes contratantes a praticar certas atividades em prol de outra, esta seja obrigada a arcar com os ônus necessários à materialização do atendimento aos seus interesses, gerando satisfação própria e uma margem de lucros para aqueloutra. A previsão de majorações periódicas para as contraprestações inerentes aos planos e seguros de 
saúde torna-se, sem sombra de quaisquer dúvidas, necessária, uma vez que nenhuma relação contratual pode sobreviver sem que esteja alicerçada em razoável suporte. Entretanto, há que se investigar se os preços exigidos pelas operadoras de planos de saúde viabilizam o dito equilíbrio econômico-financeiro e uma margem de lucratividade que não seja inescrupulosa, prejudicando os interesses e os direitos dos consumidores (GIDDENS, 1991, p. 45).

Os planos de saúde têm sido reajustados mediante a incidência de três fatores: os custos operacionais; a faixa etária; e a sinistralidade. O primeiro fator diz respeito às despesas ordinárias que as operadoras possuem para o custeio da rede de estabelecimentos e profissionais, bem como os recursos materiais necessários para que os serviços sejam prestados. O segundo refere-se à mudança da idade dos usuários e do alegado maior uso dos serviços em decorrência dessa questão. $\mathrm{O}$ terceiro concerne à utilização demasiada da rede por determinados usuários em certos períodos, gerando maiores despesas para a empresa gestora, motivo pelo qual argumenta que o reajuste faz-se necessário (SILVA, 2010, p. 145).

A majoração com esteio nos custos operacionais para os contratos posteriores à vigência da LPS é ditada, anualmente, pela Agência Nacional de Saúde Suplementar - ANS tão somente para aqueles de caráter individual ou familiar. Os planos de saúde coletivos, ou seja, os firmados por uma pessoa jurídica (empresa, fundação ou associação) para um grupo de beneficiários, são reajustados mediante acerto entre os contratantes e as operadoras. Alega a ANS que a pessoa jurídica contratante encontra-se em "pé de igualdade" com a operadora, não havendo necessidade da sua presença direta, limitando-se apenas a homologar o percentual estabelecido (SILVA, 2010, p. 145). No entanto, a prática demonstra que as operadoras pressionam os contratantes para a imposição de altos valores e ainda ameaçam a rescisão unilateral, caso não os aceitem, visto que a Lei n. 9.656/98 apenas veda a rescisão unilateral para os planos de saúde individuais, conforme dispõe o seu art. 13, parágrafo único, inciso II. Quanto aos contratos “antigos", as cláusulas acerca dos reajustes operacionais são obscuras e ambíguas, não possuindo um conteúdo claro que permita uma interpretação facilitada para os usuários. Os aumentos são, em geral, abusivos e terminam desaguando no Poder Judiciário, para que sejam coibidos ou reduzidos ${ }^{2}$.

Os reajustes com fundamento na faixa etária para os contratos firmados após o início da Lei de Planos de Saúde e antes do Estatuto do Idoso, segundo a ANS, devem obedecer à Resolução Normativa n. 06/98, que contempla 07 (sete) faixas etárias e aumentos a cada 11 $\operatorname{anos}^{3}$. Aqueles estabelecidos após a vigência da Lei n. 10.741/03, que protege os interesses e direitos dos idosos, seguirão a Resolução Normativa n. 63/03, que prevê 10 (dez) faixas etárias e aumentos a cada 4 anos. Já os planos de saúde "antigos" sofrem reajuste de acordo com as 
faixas etárias em conformidade com o que se encontra registrado no próprio contrato, causando uma série de problemas que são levados ao Poder Judiciário. Com base na decisão do Superior Tribunal de Justiça exarada no Recurso Especial n. 989.380-RN, tem-se pugnado judicialmente pela aplicação retroativa do Estatuto do Idoso a todos os demais planos de saúde, para se coibir as majorações prejudiciais aos que tenham completado 60 (sessenta) anos ou mais (SILVA, 2010, p. 147).

Os reajustes com base na sinistralidade não foram contemplados pela Lei n. 9.656/97, sendo, pois, inadmissíveis para os contratos ditos "novos", porém, a ANS editou a Resolução de Diretoria Colegiada n. 27/00, segundo a qual é possível que a operadora de plano de saúde requeira a aplicação de uma revisão técnica em caso de alta sinistralidade. Considera-se que a autarquia reguladora, ao alvedrio dos ditames legais, através de mera resolução, previu algo que atende exclusivamente aos interesses dos fornecedores, gerando sérios prejuízos para os consumidores. É cediço que tais reajustes podem e devem ser denunciados no campo judiciário até mesmo diante de contratos "antigos" que os prevejam, uma vez que, embora integrados ao conteúdo negocial, não se justificam. Isso porque as operadoras não podem querer ganhar quando há um maior uso do plano, pois constituem fundos mútuos que, quando não menos utilizados, não causam abatimentos ou reduções para os beneficiários (SILVA, 2010, p. 148).

\subsection{AUMENTOS PERIÓDICOS COM BASE NOS CUSTOS OPERACIONAIS}

A contratação dos planos e seguros de saúde pelos consumidores pressupõe o pagamento de uma mensalidade ou contraprestação a ser estipulada com base nos custos operacionais, necessários à concretização das atividades a que se obrigam os fornecedores. As despesas a serem arcadas pelas empresas do ramo da saúde suplementar serão mensuradas de acordo com custos referentes ao tipo de plano existente e aos serviços profissionais, hospitalares e complementares previstos (PRETA, 2003, p. 23). Considerando-se que os custos operacionais variam sempre, as operadoras de planos de saúde, nos contratos pré-formulados, não indicam, de forma precisa, qual será a fórmula a ser utilizada para a concretização do cálculo que servirá de base para os aumentos.

${ }^{2}$ Consultar a seguinte decisão: "REAJUSTE COMPLEMENTAR DE PLANO DE SAÚDE. APLICAÇÃO DE ÍNDICE UNILATERALMENTE ESCOLHIDO. VEDAÇÃO. CÓDIGO DE DEFESA DO CONSUMIDOR. 1.- É abusivo o reajuste de plano de saúde pelo índice que melhor atende aos interesses do fornecedor, sem que se acorde ou se dê ao consumidor qualquer informação a respeito do critério adotado. Agravo regimental improvido" (AgRg no Ag 1087391/SP, Agravo de Regimental no Agravo de Instrumento 2008/0179964-3, Rel. Min. Sidnei Beneti,

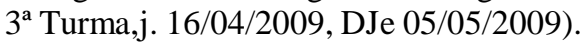

${ }^{3}$ Foram estipuladas pelo CONSU sete faixas etárias: até 17 anos, de 18 a 29, de 30 a 39, de 40 a 49, de 50 a 59 , de 60 a 69 e a partir de 70 anos e as operadoras de planos de saúde poderão, quando da transposição da idade dos consumidores de uma faixa para outra, praticar os aumentos previstos. A variação de preço, entretanto, entre a primeira e a última faixa etária somente pode ser de seis vezes no máximo. 
Constata-se que tanto nos planos coletivos quanto nos individuais, assim como nos contratos firmados antes da entrada em vigor da Lei n. 9.656/98, "ditos antigos", e nos atuais, as cláusulas relativas às contraprestações pecuniárias não registram, de forma precisa e clara, os elementos que serão utilizados no cálculo para a implementação das majorações. Alegam as operadoras que, no ato da adesão à proposta, não têm como mensurar quais serão os dispêndios necessários à cobertura contratada. O consumidor, necessitando dos serviços a que se presdipõem as operadoras a prestarem, mesmo sem que o instrumento contratual contenha, de forma clara e bem inteligível, os critérios a serem atendidos para a prática dos aumentos, aquiescem com os termos propostos (SILVA, 2010, p. 149).

Conforme salientado, a maioria dos contratos, redigidos previamente pelas operadoras de planos e seguros de saúde, não contêm cláusulas expressas e objetivas sobre a forma pela qual as contraprestações serão, periodicamente, reajustadas. Dispositivos, muitas vezes, ambíguos e confusos são inclusos na proposta contratual, frequentemente, com letras diminutas, exatamente, não possibilitando aos consumidores uma fácil compreensão. Observa-se que tais cláusulas contratuais não disponibilizam para os consumidores informações seguras sobre a periodicidade dos aumentos e nem acerca dos critérios reais e objetivos a serem atendidos para a concretização destes (ITURRASPE, 1971, p. 87).

Por tal razão, os reajustes periódicos que se pretendem para os planos coletivos têm acarretado diversas discussões nos órgãos de defesa do consumidor, já que os contratos não trazem, em seu bojo, uma previsão expressa sobre o modus como a majoração deverá ser procedida. A maioria das condições gerais da apólice dos contratos de saúde tratam dos reajustes de forma genérica, fazendo-se remissão à "unidade de serviço", sem a indicação concreta e precisa das fórmulas e índices a serem atendidos para a concretização dos aumentos.

Infere-se, pelo quanto exposto acima, que os critérios de reajuste das contraprestações pecuniárias dos planos e seguros de saúde, na prática, apresentam-se indefinidos para os usuários. A Lei n. 9.656/98, no seu art.16, inciso XI, exige que os contratos, regulamentos ou condições gerais dos produtos que sejam ofertados pelas operadoras de planos de saúde, contenham dispositivos que indiquem com clareza, dentre outros aspectos, "os critérios de reajuste e revisão das contraprestações pecuniárias" (SILVA, 2010, p. 231).

A maioria dos novos contratos coletivos formalizados pelas empresas do setor não contêm dispositivos que atendam ao quanto determinado pela referida Lei, visto que a previsão das majorações ainda continua sendo realizada de modo genérico, sem que informações precisas sejam asseguradas aos consumidores. Torna-se fundamental que os aumentos efetivados estejam em consonância com os fatores reais relativos à atividade prestada pelas 
operadoras. Além da transparência com relação às regras a serem obedecidas para a fixação dos aumentos, deve haver uma harmonização com a realidade do setor, a fim de que os consumidores e fornecedores sejam, em conjunto, beneficiados, não havendo a predominância excessiva de vantagens de uns em face aos outros. Entretanto, as operadoras argumentam que, no teor contratual, não há a possibilidade de previsão imediata de um percentual ou índice a ser obedecido quanto às majorações futuras (SILVA, 2010, p. 232). Os consumidores assustam-se com os aumentos abusivos praticados pelas operadoras com base nos custos operacionais para os planos coletivos.

\section{VIOLAÇÃO ÀS NORMAS CONSTITUCIONAIS E CONSUMERISTAS}

Os aumentos abusivos das mensalidades dos planos de saúde coletivos transgridem preceitos constitucionais e normas previstas no Código de Proteção e Defesa do Consumidor. O problema mostra-se muito mais complexo quando se constata que, mesmo diante de uma vasta gama de instrumentos normativos, os conflitos entre consumidores e empresas que atuam no ramo da saúde suplementar, ainda, persistem e ganham foros sempre mais crescentes. A boafé objetiva e a função social dos contratos, codificadas como cláusulas gerais, respectivamente, nos arts. 422 e 421 do Código Civil Pátrio, devem também servir de vetores para a avaliação dos referidos reajustes arbitrários.

\subsection{A PROTEÇÃO CONSTITUCIONAL DO DIREITO À SAÚDE E DO CONSUMIDOR}

Enuncia o art. 197 da Constituição Federal Brasileira que as ações e serviços de saúde configuram-se como de relevância pública. Faculta-se à iniciativa privada a atuação na área da saúde, conforme preconiza o artigo 199 do texto constitucional. A atuação das instituições privadas no âmbito da saúde dar-se-á - de acordo com o quanto disposto pelo parágrafo $1^{\circ}$ deste mesmo dispositivo - de forma complementar ao sistema único de saúde, obedecendo-se às diretrizes por ele elaboradas, mediante contrato de direito público ou convênio. Observa-se, entretanto, que, no Brasil, os empreendimentos privados do campo da saúde exercem um papel preponderante no atendimento aos que possam arcar com as mensalidades cobradas, deixando de ser um mero coadjuvante, para galgar um patamar de destaque e controle na seara das atividades sanitárias (SILVA, 2009, p. 707).

Os serviços considerados de relevância pública não são prestados, de forma direta, pelo Estado, mas por apresentarem uma grande importância para a sociedade, satisfazendo as necessidades dos seus membros, são caracterizados como essenciais. Tais serviços, quando 
prestados pelo setor privado, não podem ser direcionados ao atendimento exclusivo dos interesses daqueles que os dominam. Nessas circunstâncias, os aspectos que caracterizam o mercado devem ser mitigados com os interesses da população, não imperando a mera vontade dos empresários do setor em detrimento das necessidades sociais (FERRAZ; BENJAMIN, 1992, p. 38).

Ao Estado, compete, diante dos serviços de relevância pública, a tarefa primordial de observar a qualidade dos mesmos, exigindo o mínimo possível em prol da sociedade; razão pela qual o art. 197 da CF atribui ao Poder Público a competência de "regulamentar, fiscalizar e controlar a execução dos serviços de saúde", sendo que a atuação estatal reguladora tem previsão, também, no art. 174, caput, da CF. A saúde, por ser um serviço de alta relevância para a sociedade, exige do Estado "um poder de intervenção em nível mais elevado que em relação a outros serviços prestados por particulares" (SCHWARTZ, 2000, p. 52-53).

A importância da saúde é premente, sendo qualificada como direito de primeira geração, já que corresponde a um bem jurídico primário, sem o qual os seres humanos não conseguem sobreviver e nem realizar os seus projetos. A saúde não pode ser analisada, apenas, sob a ótica individual, visto que todos os indivíduos têm direito a condições de vida que lhes possibilitem um bem estar físico e mental, sendo, ainda, enquadrada como um direito de terceira geração entre os direitos transindividuais (difusos e coletivos). Há, ainda, quem sustente que a saúde seria um direito de quinta geração, porque, para a sua satisfação, os indivíduos devem ter acesso a todos os instrumentos tecnológicos e avançados que satisfaçam seu particular estado de bemestar (CANOTILHO, 2001, p. 178).

No Brasil, a despeito da Lei Maior do País erigir a saúde ao status de direito social e preconizar a relevância dos serviços que a englobem, as empresas privadas estruturadas no ramo suplementar violam, sem maiores preocupações, os preceitos constitucionais. Em diversas oportunidades, a saúde vem sendo tratada, pelas pessoas jurídicas autorizadas a explorá-la no âmbito particular, como se fosse um simples produto inserido no mercado de consumo, equiparado aos disponíveis. A importância da saúde, resguardada em sede constitucional, não vem sendo respeitada pelas empresas mencionadas. A realidade do setor de saúde suplementar do País mostra que a Constituição Federal não tem obtido, no plano fático, a efetividade esperada.

A força normativa da Constituição Federal Brasileira não pôde superar o que a realidade fática denota. $\mathrm{O}$ direito não consegue transformar a situação existente e para que as normas jurídicas, de fato, tenham efetividade, urge que já tenham sido esculpidos os fatores econômicos, sociais, políticos e culturais necessários para a implementação daquelas. Para Gunther Teubner, 
“o direito, em princípio, não está por si próprio, em posição nem de compreender suficientemente os conflitos sociais, nem de os resolver de um modo satisfatório" (TEUBNER, 2004, 109).

Nos países subdesenvolvidos ou em vias de desenvolvimento, titulares da "modernidade periférica", como ocorre com muitos localizados na América Latina, os preceitos constitucionais não são concretizados de forma suficiente. A interferência de diversificados fatores obstaculiza a materialização do conteúdo constitucional, ressaltando-se os de cunho político, subordinandose o direito à política, ou melhor, ele é dominado por uma política selvagem. "O direito é incapaz de imunizar-se contra a sua contaminação pelo poder. A política atua como parasita em relação ao direito e os antídotos jurídicos previstos no modelo textual constitucional são ineficazes contra essa ação parasitária". Jean Clam, ao tratar do pensamento de Niklas Luhmann, destaca aspectos fundamentais, afirmando que "O texto constitucional é degradado semântica e pragmaticamente no processo concretizador, de tal maneira que a reprodução autônoma do direito e a acoplagem estrutural entre direito e política é obstruída de uma forma muito abrangente" (CLAM, 2004, p. 130). Por trás da política, como assevera Luhmann, há a forte presença do fator econômico, tendo-se tornado o dinheiro o "código universal do valor" e, assim sendo, o direito e as demais instituições sociais não conseguiram neutralizar-se diante da força do capital (LUHMANN, 1986, p. 56).

Inviabilizada a produção de efeitos concretos a partir das normas constitucionais, a lei, intitulada de fundamental, e que deveria ser suprema neste País, não passa de um simples "papel acoplado por diversas promessas", que não consegue produzir efeitos na vida social. De um instrumento jurídico que carrega as normas que regem a estrutura básica do País e os direitos e garantias essenciais para a convivência social, a Constituição transforma-se em um mero simbolismo. Numa ordem social em que os dispositivos constitucionais não ganham concretude no "mundo da vida", as demais normas advindas do texto dito maior, ipso facto, não conseguiram sequer contribuir para que a realidade social perceba que trazem em si uma pequena força. Reputando a Constituição um mero simbolismo - em presença do que foi captado da realidade brasileira em termos de salvaguarda dos direitos individuais e sociais fundamentais (NEVES, 1994, p. 161).

No campo das relações privadas, o direito à saúde vem sendo tratado como uma mercadoria qualquer, tendo sido englobado pela lógica do capitalismo, que, para a obtenção desmedida de lucros, não se preocupa com a natureza do bem manipulado. O direito à saúde, que está, de forma direta e inseparável, imbricado com a vida dos indivíduos, constituindo-se, pois, num bem jurídico de valor inestimável, terminou convertendo-se em mera "coisa", 
manipulável de acordo com as regras do jogo capitalista, para atender ao bel prazer dos que dominam o âmbito privado.

Seguindo o modelo já enraizado pelo sistema capitalista, as operadoras de planos e seguros de saúde estabelecem, nos contratos de adesão ofertados ao público, diversas cláusulas abusivas, para satisfazerem a sua sanha de lucratividade em detrimento dos direitos dos consumidores, como se as relações privadas fossem inabaláveis pelo conteúdo do direito à saúde (SANTOS, 2005, p. 89). Em diversas circunstâncias, aquelas pessoas jurídicas atuam de forma abusiva, mesmo sem ter uma previsão contratual, executando práticas completamente irregulares. As majorações desmedidas das mensalidades dos planos e seguros de saúde constituem uma das mais perversas faces da atuação inescrupulosa das empresas que atuam no ramo, demonstrando que as normas constitucionais que asseguram a relevância destes serviços não estão sendo respeitadas.

Importante será resgatar a força normativa da Constituição Federal deste País para que a assistência suplementar à saúde, na condição de serviço de relevância pública, não continue sendo estigmatizada com as majorações iníquas das mensalidades dos planos de saúde. Para a defesa dos usuários dos planos e seguros de saúde em face das posturas iníquas adotadas pelas operadoras de planos de saúde, mister será recorrer-se ao quanto disposto pelos arts. $5^{\circ}$, inciso XXXII, e 170, inciso V, Carta Magna Brasileira; o que demonstra a imperiosidade de que as normas constitucionais tenham plena efetividade. Isto porque a Constituição Federal de 1988 enumera a defesa dos consumidores com um dos direitos essenciais para a constituição de uma sociedade livre, justa e solidária e a elenca como um dos princípios gerais da atividade econômica, para seja ser concretizada a justiça social.

\subsection{NORMAS CONSUMERISTAS VIOLADAS, A BOA-FÉ OBJETIVA E A FUNÇÃO SOCIAL DO CONTRATO}

No Brasil, a Política Nacional das Relações de Consumo tem por escopo atender às necessidades dos consumidores em geral, dentre as quais a obtenção de serviços de saúde adequados e eficientes. Para que seja respeitada a dignidade dos usuários dos planos de saúde e protegidos os seus interesses econômicos, as relações contratuais devem estar pautadas em cláusulas que primem pela transparência e a harmonia dos direitos, conforme previsto no caput do art. $4^{\circ}$ do Código de Proteção e Defesa do Consumidor.

O princípio da harmonia nas relações de consumo - um dos baluartes na Política Nacional, previsto no inciso III daquele dispositivo normativo - pressupõe que as negociações estejam sempre baseadas na boa-fé e no equilíbrio entre os interesses dos fornecedores e 
consumidores. O respeito a tal princípio somente será possível quando, nos instrumentos contratuais, os fornecedores estipulem cláusulas compatíveis com a eticidade, não se aproveitando da condição privilegiada de poderem, previamente, traçar o conteúdo daqueles em desfavor de inúmeros consumidores (RIPERT, 1937, 1947).

Face à constante inserção de dispositivos irregulares nos instrumentos contratuais, houve por bem o CDC estatuir, no art. $6^{\circ}$, incisos IV e $\mathrm{V}$, dois direitos básicos dos consumidores, evocados, com bastante frequência, pelos usuários de planos de saúde ao questionarem os aumentos abusivos por parte das operadoras de planos de saúde. Tratam os mencionados dispositivos da proteção dos consumidores contra práticas e cláusulas abusivas impostas pelos fornecedores e a possibilidade de modificação das disposições que ensejem prestações desproporcionais. Joaquim de Sousa Ribeiro assevera que os contratos de adesão são estigmatizados por cláusulas arbitrárias diante do fato de o fornecedor deter o poder de redigilos unilateralmente (RIBEIRO, 1999, p. 439).

Decorrendo os planos e seguros-saúde de uma relação contratual concretizada mediante a modalidade de adesão dos consumidores a uma estrutura prévia elaborada pelos fornecedores, sem que haja uma discussão sobre o conteúdo, há a facilidade de serem previstas diversas cláusulas abusivas. Jean Calais Auloy, aduz que "Sendo a redação dos contratos de adesão obra exclusiva dos profissionais, inclinaram-se estes a inserir cláusulas exageradamente vantajosas em seu favor. Desde o instante em que o consumidor assinava o contrato, supunha-se que tinha livremente aceitado todas as disposições” (CALAIS AULOY, 1986, p. 141). Tais cláusulas são previstas no art. 51 do Código de Proteção e Defesa do Consumidor - CDC, sendo consideradas nulas de pleno direito.

A identificação das cláusulas abusivas pode ser concretizada por meio dos critérios formal e material (FONSECA, 1993, p. 184). Mediante a análise de natureza formal, observase se os consumidores tiveram a oportunidade de conhecimento prévio do contrato, assim como se este encontra-se redigido em termos claros e com caracteres ostensivos e legíveis, atendendose ao quanto disposto pelos arts. 46 e 47 do Código de Proteção e Defesa do Consumidor. O arrazoado exposto demonstra que, nos contratos firmados por consumidores que objetivam adquirir um plano de saúde, a abusividade de natureza formal ocorre com extrema frequência, uma vez que a maioria daqueles não se inteira do completo teor do instrumento contratual, até porque este não lhes é disponibilizado, bem como as cláusulas não são redigidas de forma clara e precisa. Já fora dito, em inúmeras oportunidades, que as cláusulas que preveem os aumentos com base nos custos operacionais não se fundamentam em critérios precisos e claros. Sob o 
aspecto material, averígua-se, nas hipóteses concretas, a configuração das cláusulas previstas no art. 51 do CDC, cuja delimitação, logo a seguir, será exposta.

Ao discorrer sobre o conceito das cláusulas abusivas, afirma Alterini, que deverão ser consideradas não combinadas ou irregulares as estipulações que desnaturalizem as obrigações previstas nos contratos. O conceito de cláusulas abusivas apresenta-se, assim, elástico e abrangente, englobando toda e qualquer previsão que afete o equilíbrio que deverá vigorar nas relações contratuais existentes entre os interessados, acarretando vantagens desmedidas para um em detrimento do outro (ALTERINI, 2000, p. 98). No que concerne aos aumentos abusivos praticados pelos planos e seguros de saúde, destacam-se os incisos X e XIII do art. 51 do CDC que tratam, respectivamente, da permissão de o fornecedor, direta ou indiretamente, concretizar a variação do preço de maneira unilateral, e a que autoriza ao fornecedor modificar, por si somente, o conteúdo ou a qualidade do contrato, após sua celebração. As cláusulas que possibilitam aos fornecedores alterarem, de forma unilateral, o preço dos produtos ou serviços ou a essência do contrato são tidas como "iníquas, abusivas e exageradas" (ALMEIDA, 2002, p. 121), ferindo, frontalmente, a dignidade do consumidor e o equilíbrio contratual, pois violam a boa-fé e a equidade que devem figurar na relação contratual consumerista.

A cláusula justa será aquela que esteja em conformidade com os padrões exercidos em sociedade e, de acordo com a estrutura contratual estabelecida, sendo fundamental a sua presença para que o contrato seja concebido como justo e regular (LARENZ, 1958, p. 344). O conceito, então, de cláusula abusiva encontra-se, intimamente, entrelaçado com a moralidade média vigente em certa sociedade e com a necessidade de manutenção do equilíbrio entre as partes contratantes. Thierry Bourgoignie, ao discorrer sobre o conceito de abusividade das cláusulas previstas nos contratos de consumo, defende que a normalidade de certo dispositivo dependerá do respeito aos ditames da ordem pública e dos bons costumes vigentes, contribuindo para a harmonia contratual (1993, p. 13).

Nos contratos coletivos relativos aos planos e seguros de saúde, pode-se verificar a existência de cláusulas que permitem aos fornecedores a variação do preço de forma unilateral, sem que os consumidores sejam consultados, nem tampouco a autarquia incumbida de fiscalizar a atuação das empresas que desenvolvem atividades no ramo. O parágrafo $1^{\circ}$ do mencionado art. 51, nos seus incisos I a III, reza que se presume o exagero da vantagem quando esta ofende os princípios fundamentais do sistema jurídico que integre, restrinja direitos ou obrigações fundamentais inerentes à natureza do contrato, de modo a ameaçar seu objeto ou o equilíbrio contratual, ou se mostra excessivamente onerosa para o consumidor, considerando-se a natureza 
e o conteúdo do contrato, o interesse das partes e outras circunstâncias peculiares ao caso (REZZÓNICO, 1987, p. 101).

As empresas do setor de saúde suplementar, ao imporem aumentos das contraprestações pecuniárias dos planos coletivos com base em cláusulas genéricas sobre os custos operacionais, sem que estes reflitam, de forma verídica, a sua realidade econômico-financeira e os valores que têm sido despendidos para a concretização do objeto contratual, terminam praticando uma majoração sem fundamento legítimo e, por via de consequência, obtendo vantagem desmedida. As majorações encetadas com esteio nos custos operacionais, como já salientado, devem estar embasadas em critérios precisos e não genéricos, regulamentados pelo órgão fiscalizatório e, devidamente, informados aos consumidores no momento da contratação. Na realidade, porém, tal prática não ocorre, sendo os consumidores conduzidos, pela necessidade de adquirirem um plano de saúde, a subscreverem propostas que trazem informações abstratas sobre as fórmulas de majoração das mensalidades.

Um dos grandes problemas dos aumentos das contraprestações pecuniárias dos planos de saúde com fundamento nos custos operacionais corresponde à possibilidade inserida nos contratos, principalmente os considerados "antigos", de as operadoras alterarem os valores ao seu bel-prazer, sem que tenham de obter autorização do órgão público competente, e muito menos ouvir os consumidores. No momento da contratação, o problema passa despercebido, pois os consumidores sequer se inteiram do conteúdo dos contratos que estão a firmar, mas, $a$ posteriori, as operadoras de planos e seguros de saúde, valendo-se destas cláusulas como verdadeiros escudos, lançam os aumentos abusivos, alterando o índice que deveriam atender (SILVA, 2010, p. 234).

Com relação aos aumentos fundamentados nos custos operacionais, as empresas, valendo-se da existência de cláusulas genéricas nos instrumentos contratuais, em diversas oportunidades, fazem uso de índices que melhor atendam aos seus interesses, terminando por prejudicar, flagrantemente, os interesses dos consumidores. Medida imperiosa será a exigência de que todos os contratos, quer sejam ditos "antigos" ou atuais, contenham previsão expressa sobre o índice a ser considerado para a prática dos aumentos, assegurando para os consumidores que não serão apanhados de surpresa com a imposição de majorações baseadas em indicadores que atendam, exclusivamente, aos anseios da classe empresarial do ramo da saúde suplementar. Ademais, a Agência Nacional de Saúde Suplementar (ANS) deveria, por meio de Resolução, anualmente, estabelecer os percentuais de reajustes dos planos coletivos.

Não se pode continuar admitindo que as empresas do ramo continuem impondo percentuais desmedidos em prejuízo da coletividade usuária, causando um desequilíbrio 
contratual. Por vantagem excessiva entende-se o resultado positivo conseguido pelo fornecedor de produtos e serviços, desrespeitando os princípios fundamentais que emanam do ordenamento jurídico, contribuindo para o desequilíbrio da relação contratual e, em determinadas circunstâncias, deixando de cumprir com as obrigações inerentes ao que foi pactuado. Os fornecedores aproveitam-se, muitas vezes, da condição mais favorável diante dos consumidores - uma vez que dispõem de conhecimentos técnicos e posição econômica superior - para conseguirem benefícios indevidos.

Inicialmente, o Código de Proteção e Defesa do Consumidor, não previa, a título de prática abusiva, a elevação injustificada de preços. Tal prática abusiva veio a ser incluída no art. 39 por determinação da Lei n. 8.884, de 11 de junho de 1994, conforme estabelecia o seu art. 87. A essência desta norma consiste em exigir que, para a majoração dos valores dos produtos e serviços comercializados, seja aquilatado se os fatores a estes vinculados sofreram alterações, como, v.g. aumento do valor da matéria-prima, vencimentos dos encarregados da produção, impostos incidentes, etc. Inaceitável, portanto, será que os fornecedores, para atenderem, unicamente, aos seus interesses, elevem preços em prejuízo dos consumidores.

Pensar e aplicar o direito diante dos vários acontecimentos levados para o espectro judiciário exigia, e ainda exige, muito mais que a simples utilização do procedimento lógicodedutivo (GOMES; VARELA, 1977, p. 199). O pensamento sistemático, antes considerado como suficiente para a identificação dos casos e a obtenção de soluções, demonstrou insuficiência, entrando em cena o raciocínio problemático, tão bem delimitado por Theodor Viehweg (1979, p. 34). Para que o conteúdo normativo das situações concretas seja identificado, deve-se fazer uso do procedimento de valoração; o que exigirá o recurso às cláusulas gerais e aos princípios jurídicos. Segundo Robert Alexy, os princípios são "mandatos de otimização" que podem ser atendidos em várias circunstâncias, mas para tal exigem uma harmonização das “possibilidades fáticas" e "possibilidades jurídicas”, figurando estas em um âmbito definido por “princípios e regras que jogam em sentido contrário". Neste diapasão, a boa-fé e a função social do contrato nascem como cláusulas gerais, que servem de instrumento para a consecução da tarefa valorativa (1988, v. 5. p. 143) .

Em alguns ordenamentos jurídicos, como no brasileiro, tanto a boa-fé quanto a função social já foram contempladas pela estrutura normativa, constituindo cláusulas gerais. Configuradas como cláusulas de cunho genérico, a boa-fé e a funcão social do contrato não deixam de exercer influência de grande porte na interpretação e aplicação das normas jurídicas (WIEACKER, 1986, p. 123). A importância das cláusulas gerais foi salientada por Joseph Esser 
ao afirmar que "devemos nos habituar a utilizar as cláusulas gerais como topoi, tais como a boafé, na qualidade de criação judicial das instituições" (1961, p. 83).

Examinar os fatos de forma genérica, como anteriormente se recomendava, por intermédio de meros encaixes nas estruturas normativas, não mais será possível. Urge que, nos dias atuais, os operadores do direito examinem os casos em toda a sua potencialidade, realizando-se uma "mescla de indução e dedução", analisando o conteúdo da norma, mas não se limitando a este, voltando-se para os precedentes judiciais e quaisquer elementos ou aspectos qualificados como importantes (ÁVILA, 1997, p. 445). Para Larenz, na apreciação do caso concreto, “o juiz não tem apenas de 'generalizar' o caso; tem também de individualizar até certo ponto o critério; e precisamente por isso, a sua atividade não se esgota na subsunção" (LARENZ, 1991, p. 519).

$\mathrm{Na}$ condição de cláusulas gerais, a função social e a boa-fé estão previstas no ordenamento jurídico nacional mediante uma linguagem de tessitura intencionalmente "'aberta', 'fluida' ou vaga"” (MARTINS-COSTA, 1999, p. 103), que permitem aos profissionais do direito a interpretação e a aplicação das normas jurídicas, com possibilidades maiores de se obterem decisões que melhor se adequem aos casos concretos, alcançando-se a justiça esperada (RODOTÁ, 1969, p. 57). No que concerne aos contratos inerentes aos planos de saúde, com a presença da boa-fé e da função social, torna-se muito robusta a argumentação de que tais relações jurídicas devem primar pelo equilíbrio do ponto de vista interno e externo (HORVAT, 1999, p. 45).

As inoportunas majorações das contraprestações pecuniárias dos planos coletivos de saúde afetam a boa-fé e a função social do contrato na condição de cláusulas fundamentais que devem reger o vínculo jurídico estabelecido. Os consumidores, ao firmarem planos de saúde, acreditam que estarão participando de uma relação saudável, caracterizada pela harmonia e equilíbrio, mas esta confiança será prejudicada com os aumentos irregulares praticados (GODOY, 2004, p. 67). Na medida em que a relação jurídica entre fornecedores de planos de saúde e consumidores não funciona bem, todos os que estão inseridos na situação são atingidos, assim como a sociedade vai sofrer com os reflexos.

Os aumentos abusivos das mensalidades dos planos coletivos de saúde, analisados anteriormente, ferem o sentimento de confiança depositado pelos consumidores no relacionamento contratual. Na condição de cláusula geral, a boa-fé será utilizada para interpretar, integrar e controlar as majorações iníquas das contraprestações pecuniárias dos planos de saúde (MENEZES CORDEIRO, 2001, p. 454). A massa de indivíduos vinculada à relação contratual sofrerá impactos negativos - no que consiste um dos motivos a exigir das 
operadoras de planos de saúde uma atuação responsável. Por outra via, as majorações indevidas darão origem à exclusão de diversos usuários, que engrossarão as filas do sistema público, dificultando, ainda mais, o acesso dos carentes, bem como poderão engendrar demandas judiciais que trarão consequências negativas para o moroso e atribulado aparato jurisdicional.

Conforme visto alhures, as desmedidas majorações anuais das mensalidades dos planos coletivos de saúde transgridem frontalmente dispositivos constitucionais referentes à proteção consumidor e ao direito fundamental de acesso à saúde. Na esfera infraconstitucional, vislumbra-se um verdadeiro descompasso com as normas aludidas emanadas da Lei n. 8.078/90, atingindo também as cláusulas gerais da boa-fé objetiva e da função social dos contratos - problema que pressupõe providências sérias e enérgicas. Não obstante não se desconsidere a autonomia privada das operadoras de planos de saúde e a livre iniciativa consagrada em sede constitucional, é essencial que, com base no princípio da intervenção estatal, a ANS regulamente e fiscalize não somente os percentuais de reajuste operacional dos planos individuais, acompanhando também os contratos coletivos (BARCELLONA, 1969, p. 154).

\section{CONCLUSÃO}

1. Tendo por objeto a saúde, bem primordial que se sobrepõe a qualquer outro, pois sem ela, o ser humano fenece e não terá condições de desfrutar dos demais, os contratos de planos de saúde são caracterizados por aspectos singulares que exigiram do legislador a criação de um diploma específico. Identificados como contratos que não são firmados para o atendimento de necessidades imediatas, sendo pois marcados pela longevidade, os planos de saúde suscitam uma atenção especial, já que se protraem no tempo para atender às demandas dos consumidores. Além do fator temporal, tais contratos dão origem a fundos que servirão de embasamento para o atendimento de um razoável número de usuários, havendo uma flagrante conotação coletiva. Caracterizados, por conseguinte, como contratos "cativos de longa duração", os planos de saúde suscitam uma fiscalização intensa por parte dos órgãos competentes, para que os interesses e os direitos dos consumidores não sejam prejudicados.

2. Os aspectos singulares que caracterizam os contratos de saúde exigem uma atuação fiscalizatória do Poder Público. A prestação de serviços de saúde por particulares apenas ocorre mediante a chancela do aparato estatal e exige um acompanhamento frequente por parte dos órgãos fiscalizatórios. A importância do objeto contratual, a presença de uma multiplicidade de consumidores, a extensão temporal da relação contratual e ainda a submissão dos consumidores a propostas previamente elaboradas ao sabor dos interesses das empresas são peculiaridades que 
suscitam uma atenção redobrada do Estado. A presença estatal, ao executar a necessária tarefa fiscalizatória junto às operadoras, constitui medida fundamental para se evitar que disposições abusivas vicejem nos instrumentos contratuais.

3. Nesse panorama em que o Poder Público não oferta à população um sistema de saúde eficiente nem o fiscaliza de modo satisfatório, as empresas que atuam na área da saúde suplementar reinam sem maiores freios e aproveitam-se da situação para imporem majorações das mensalidades de modo abusivo, e em desrespeito aos direitos dos usuários. De tais circunstâncias resultam diversos conflitos que desembocam na esfera dos órgãos incumbidos de tratarem da questão, pois os consumidores, normalmente, com o desiderato de resolverem o problema, não conseguem manter qualquer diálogo com as empresas. No que concerne aos planos de saúde coletivos, os reajustes com base nos custos operacionais, por não serem monitorados pela Agência Nacional de Saúde Suplementar (ANS), têm sido objeto de diversas demandas judiciais, visto que albergam aspectos arbitrários.

4. A saúde, dentro desse panorama, deixa de ser um direito de todos os cidadãos, para se tornar uma mercadoria negociada pelas operadoras de planos privados. Transformando-se, pois, em um mero objeto do comércio, afeta-se sua condição de direito fundamental, ocorrendo a verdadeira "coisificação" da saúde. A nova etapa do capitalismo, caracterizada pela globalização e pela era dos capitais voláteis, contribui para a visão de que tudo pode ser comercializado, até mesmo a saúde, como se fosse um objeto de compra e venda. Os planos de saúde coletivos albergam os interesses de uma multiplicidade de sujeitos e não podem continuar sendo majorados sem que a autarquia reguladora participe do procedimento correspondente.

5. Os aumentos abusivos das mensalidades dos planos de saúde coletivo transgridem regras constantes na Constituição Federal e no Código de Proteção e Defesa do Consumidor. Além das normas previstas nesses diplomas legais, duas cláusulas gerais, de extrema importância para a análise da questão, são violadas, de forma flagrante, pelas operadoras de planos de saúde ao majorarem, indevidamente, as contraprestações pecuniárias dos contratos coletivos, quais sejam: a boa-fé objetiva e a função social dos contratos, estando a primeira prevista, expressamente, no CDC, enquanto a segunda é inferida deste Diploma Legal e encontra guarida no Código Civil Brasileiro.

6. Reinando as operadoras de planos de saúde em um espaço de completo domínio, conforme já explicitado, pela desestruturação e a precariedade da saúde pública, atuam, frequentemente, praticando excessos e abusos. Os serviços prestados pelos planos de saúde, também, não podem ser vislumbrados pela ótica estritamente privada, pois são qualificados como de "relevância pública", conforme preconizado pelo art. 197 da Constituição Federal de 
1988 e, consequentemente, devem estar pautados em requisitos e princípios similares aos que norteiam o setor público. A despeito da ineficácia do Estado quanto ao tratamento das questões atinentes à saúde, este não deve admitir que as operadoras de planos de saúde atuem de forma inescrupulosa, sem quaisquer freios. Ao poder público compete a tarefa de fiscalizar, com seriedade, aquelas pessoas jurídicas, e a sociedade, também, não pode e nem deve assistir, inerte e atônita, aos seus desmandos, pois, diante das práticas abusivas, muitos consumidores terminam sendo obrigados a se desvincularem da relação contratual e passam a integrar a massa dos que dependem do sistema público de saúde, dificultando, ainda mais, a execução deste e o acesso dos mais necessitados.

7. Propugna que a Agência Nacional de Saúde Suplementar (ANS) não continue isentando-se da responsabilidade quanto ao acompanhamento dos planos de saúde coletivos no que concerne aos reajustes anuais com esteio nos custos operacionais. Dessa forma, torna-se fundamental que edite Resolução Normativa disciplinando que os contratos coletivos de assistência suplementar à saúde obedeçam aos percentuais anuais de reajustes operacionais fixados pela autarquia reguladora. Caso a ANS continue esquivando-se de tal responsabilidade, os instrumentos que integram o Sistema Nacional de Defesa do Consumidor (SNDC), previstos no art. $5^{\circ}$, incisos I a V, da Lei n. 8.078/90, devem adotar as providências cabíveis para que, judicialmente, venha a ser compelida a fixar os referidos índices em caráter anual.

\section{REFERÊNCIAS}

ALEXY, Robert. Sistema jurídico, princípios jurídicos y razón practica. Rev. Doxa, Alicante, 1988, v. 5. p. 143.

ALMEIDA, Célia et al. Regulação e saúde: estrutura, evolução e perspectivas da assistência médica suplementar. São Paulo: Cortez, 2000.

ALMEIDA, João Batista de. A proteção jurídica do consumidor. 3. ed. São Paulo: Saraiva, 2014.

ALTERINI, Atilio Anibal. Contratos - Civiles y Comerciales de Consumo. Buenos Aires: Abeledo- Perrot, 1999.

Os contratos de consumo e as cláusulas abusivas. Revista de Direito do Consumidor. São Paulo, n- 31, 2000, p. 17.

ÁVILA, Humberto Ávila. Subsunção e concreção na aplicação do direito. In: MEDEIROS, Antônio Paulo Cachapuz de (Org.). Faculdade de Direito da PUCRGS: o ensino jurídico no limiar do novo século. Porto Alegre: Edipuc-RS, 1997. 
BARCELLONA, Pietro. Intervento statale e autonomia privata nella disciplina dei rapporti economici. Milão: Dott. A. Giuffrè Editore, 1969.

BAUMAN, Zygmunt. Modernidade e Ambivalência. Trad. Marcus Penchel. Rio de Janeiro: Jorge Zahar Editor, 1999.

BENJAMIN, Antônio Herman de Vasconcelos e. A defesa do consumidor e o direito como instrumento de mobilização social. Rio de Janeiro: Ed. Manad, 1998.

BERGER, Peter L.; LUCKMANN, Thomas. A Construção Social da Realidade. Trad. Floriano de Souza Fernandes. Petrópolis: Vozes, 1973.

BOBBIO, Norberto. A era dos direitos. Trad. Carlos Nelson Coutinho. Rio de Janeiro: Campus, 1992.

BOTTESINI, Maury Ângelo; MACHADO, Mauro Conti. Lei dos Planos e Seguros de Saúde. 2. ed. rev.ampl. e atual. São Paulo: Revista dos Tribunais, 2005.

BOURGOIGNIE, Thierry. O conceito de abusividade em relação aos consumidores e a necessidade de seu controle através de uma cláusula geral. Revista de Direito do Consumidor. São Paulo, no 6, p. 7-16, abr./jun. 93.

CALAIS-AULOY, Jean; STEINMETZ, Frank. Droit de la consommation, 3. ed. Paris: Dalloz, 1986.

CANARIS, Claus-Wilhelm. Pensamento sistemático e conceito de sistema na ciência do direito. Trad. A. Menezes Cordeiro. Lisboa: Fundação Calouste Gulbekian, 1989.

CANOTILHO, José Joaquim Gomes.Constituição Dirigente e Vinculação do Legislador. Contributo para a Compreensão das Normas Constitucionais Programáticas. 2. ed. Coimbra: Coimbra Editora, 2001.

CAPPELLETTI, Mauro. Formazioni sociali e interessi di gruppo davanti alla giustizia civile. Rivista di Diritto processuale, 3, 1975.

CARVAlHO SOBRINHO, Lineu Rodrigues. Seguros e Planos de Saúde. São Paulo: Juarez Oliveira, 2001.

CLAM, Jean. Monetarização, generalização da cobiça e paradoxo do direito. In ARNAUD, André-Jean; LOPES JR., Dalmir (Orgs.). Niklas Luhmann: do sistema social à sociologia jurídica. Trads. Dalmir Lopes Júnior, Daniele Andréa da Silva Manão e Flávio Elias Riche. Rio de Janeiro: Lumen Juris, 2004, p. 130.

COHN, Amélia et al. A saúde como direito e como serviço. $3^{\mathrm{a}}$. ed. São Paulo: Cortez, 2002.

COSTANZA, Maria. Profili dell' interpretazione del contratto secondo buona fede. Milão: Dott A. Giuffrè Editore, 1989.

COUTO E SILVA, Clóvis do. A obrigação como processo. São Paulo: J. Bushatsky, 1976. 
O princípio da boa-fé no direito brasileiro e português. São Paulo: Revista dos Tribunais, 1980.

CRUET, Jean. A vida do direito e a inutilidade das leis. 2. ed. Trad. Editora Jurídica CLEDIJUR. São Paulo: CLEDIJUR Editora Jurídica, 2003.

ESSER, Josef. Principio y norma en la elaboración jurisprudencial del derecho privado. Trad. Eduardo Valintí Fiol. Barcelona: Bosch, 1961.

FARINA, Juan M. Defensa del consumidor y del usuario. $3^{\mathrm{a}}$. ed. atual. e ampl. Buenos Aires: Astrea, 2004.

FERNANDES NETO, Antônio Joaquim. Plano de Saúde e Direito do Consumidor. São Paulo: Del Rey, 2002.

FERRAZ, Antonio Augusto Mello de Camargo; BENJAMIN, Antonio Herman de Vasconcellos e. O conceito de ' relevância pública' na Constituição Federal. In: DALLARI, Sueli Gandolfi.(org.) $O$ conceito constitucional de relevância pública. Brasília: Organização Panamericana de Saúde, 1992.

FONSECA, João Bosco Leopoldino da. Cláusulas Abusivas nos Contratos. Rio de Janeiro: Forense, 1993.

GHERSI, Carlos Alberto; WEINGARTEN, Celia; IPPOLITO, Silvia C. Contrato de medicina prepaga. 2. ed. atual. e ampl. Buenos Aires: Astrea, 1999.

GIDDENS, Anthony. As Conseqüências da Modernidade. 4. ed. Trad. Raul Fiker. São Paulo: UNESP, 1991.

GILMORE, Grant. The death of contract. Michigan: Ohio State University Press, 1995.

GIORDANO, Alessandro. I contratti per adesione. Milão: Giuffrè, 1951.

GODOY, Cláudio Luiz Bueno de. Função Social do Contrato de acordo com o Novo Código Civil. São Paulo: Saraiva, 2004.

GOMES, Orlando. Contrato de Adesão. São Paulo: Revista dos Tribunais, 1972.

. Contratos. $17^{\mathrm{a}}$. ed. Rio de Janeiro: Forense, 1996.

. Transformações Gerais do Direito das Obrigações 2a ${ }^{a}$ ed. São Paulo: Revista do Tribunais, 1967.

. A Crise do Direito. São Paulo: Max Limonad. 1955.

A caminho dos microssistemas. In: GOMES, Orlando (coord.). Novos temas do direito civil. Rio de Janeiro: Forense, 1983.

; VARELA, Antunes. Direito Econômico. São Paulo: Saraiva, 1977. 
HORVAT, Marjan. Osservazioni sulla bona fides, nel diritto romano obbligatorio. Studi in onore di Vicenzo Arangio Ruiz. Napoli: Jovene, 1999.

ITURRASPE, Jorge Mosset. Teoría general del contrato, 2. ed., Rosario: Orbir, 1971, p. 87.

KERLINGER, Fred N. Metodologia da Pesquisa em Ciências Sociais: um tratamento conceitual. São Paulo: EPU, 1980.

LARENZ, Karl. Derecho Civil. Parte General. Trad. Miguel Izquierdo y Macías- Picavea. Madri: Edersa, 1978.

. Derecho de obligaciones. Trad. Jaime Santos Briz. Madri: Edersa, 1978.

. Derecho justo. Fundamentos de ética jurídica. Trad. Luis Dies-Picazo. Madri: Editorial Civitas S.A, 1985.

. Metodologia da Ciência do Direito 3. ed. Trad. José Lamego. Lisboa: Fundação Calouste Gulbekian, 1991.

LUHMANN, Niklas. Love as passion: The Codification of Intimacy. Trad. Jeremy Gaines e Doris L. Jones. Cambridge, Mass: Hartad University Press, 1986.

MACEDO JUNIOR, Ronaldo Porto. Contratos Relacionais e Defesa do Consumidor. São Paulo: Max Limonad, 1998.

MARANHÃO, Clayton. Tutela jurisdicional do direito à saúde. Coleção Temas Atuais de Direito Processual Civil. São Paulo: Revista dos Tribunais, 2003, v.7.

MARQUES, Cláudia Lima. Contratos no Código de Defesa do Consumidor, 6. ed. rev. atual. e ampl. São Paulo: Revista dos Tribunais, 2014.

BENJAMIN, Antônio Herman V. et al. Comentários ao Código de Defesa do Consumidor. São Paulo: Revista dos Tribunais, 2004.

MARTINS-COSTA, Judith. A boa-fé no direito privado: sistema e tópica no processo obrigacional. São Paulo: Revista dos Tribunais, 1999.

MENEZES CORDEIRO, António Manuel da Rocha e. A Boa Fé no Direito Civil. Coimbra: Almedina, 2001.

NERY JÚNIOR, Nelson et al. Código Brasileiro de Defesa do Consumidor Comentado pelos Autores do Anteprojeto. 9. ed. rev. ampl. e atual. Rio de Janeiro/São Paulo: Forense Universitária, 2009.

NEVES, Marcelo. A Constituição Simbólica. São Paulo: Acadêmica, 1994.

PRETA, Horácio Cata. Agência Nacional de Saúde Suplementar - Fórum de Saúde Suplementar. Análise da Política de Reajuste para Planos Individuais e Coletivos implementados pela ANS, passim, 2003. 
REZZÓNICO, Juan Carlos. Contratos con clausulas predispuestas. Buenos Aires: Astrea, 1987.

RIBEIRO, Joaquim de Souza. O problema do contrato- as cláusulas contratuais gerais e o princípio da liberdade contratual. Coimbra: Almedina, 1990.

RIEG, Alfred. L' autonomie de la volonté et leis droits fondamentaux em droit privé allemand. Bruxelas: Bruylant, 2000.

RIPERT, Georges. A Regra Moral nas Obrigações Civis. Trad. Osório de Oliveira. São Paulo: Saraiva, 1937.

. Aspectos jurídicos do capitalismo moderno. Trad. Gilda G. de Azevedo. Rio de Janeiro: Freitas Bastos, 1947.

RIZZATTO NUNES, Luiz Antônio. Comentários à Lei dos Planos Privados de Assistência à Saúde. 2. ed. rev. mod. e ampl. São Paulo: Saraiva, 2000.

RODOTÁ, Stefano. Le fonti di integrazione del contratto. Milão: Dott A. Giuffrè Editore, 1969.

SANTOS, Boaventura de Sousa. Pela Mão de Alice. 10. ed. São Paulo: Cortez Editora, 2005.

SAVATIER, R. Les métamorphoses économiques et sociales du droit civil d'aujourd'hui. 10. ed. Paris: Dalloz, 1952.

SCHAEFER, Fernanda. Responsabilidade Civil dos planos e seguros de saúde. Curitiba: Juruá, 2004.

SILVA, José Afonso da Silva. Curso de Direito Constitucional positivo. São Paulo: Malheiros, 2009.

SCHWARTZ, Germano André Doederlein. Direito à saúde: efetivação de uma perspectiva sistêmica. Porto Alegre: Livraria do Advogado, 2000.

SILVA, Joseane Suzart Lopes. Planos de Saúde e Boa-Fé Objetiva. Uma Abordagem Crítica acerca dos Reajustes Abusivos. 2. ed. rev. atual. e ampl. Salvador: Juspodivm, 2010.

TEUBNER, Gunther. As múltiplas alienações do direito: a mais-valia social do décimo segundo camelo. In ARNAUD, André-Jean; LOPES JR., Dalmir (Orgs.). Niklas Luhmann: do sistema social à sociologia jurídica. Trad. Dalmir Lopes Júnior, Daniele Andréa da Silva Manão e Flávio Elias Riche. Rio de Janeiro: Lumen Juris, 2004.

VIEHWEG, Theodor. Tópica e Jurisprudência. Trad.Tércio Sampaio Ferraz Júnior. Brasília: Departamento de Imprensa Nacional, 1979.

WEICHERT, Marlon Alberto. Saúde e Federação na Constituição Brasileira. Rio de Janeiro: Lumen Juris, 2004.

WIEACKER, Franz. El Princípio General de la Buena Fé. Trad. José Luis Carro. Madri: Civitas, 1986. 